\title{
Photobiomodulation of fresh bone marrow aspirate for regenerative therapy
}

\author{
Fotobiomodulação de aspiradlo de medula óssea fresco para terapia regenerativa \\ Fotobiomodulación de aspirado de médula ósea fresca para terapia regenerativa
}

Received: 08/18/2021 | Reviewed: 08/22/2021 | Accept: 08/24/2021 | Published: 08/25/2021

Carolina dos Santos Santinoni

ORCID: https://orcid.org/0000-0001-5153-2419

University of Western Sao Paulo, Brazil

E-mail: carolsantinoni@msn.com

Liziana Jancos Calles

ORCID: https://orcid.org/0000-0001-8268-5055

University of Western Sao Paulo, Brazil

E-mail: lizianaa@gmail.com

Nathália Laís Farias

ORCID: https://orcid.org/0000-0002-8328-8446 University of Western Sao Paulo, Brazil E-mail: nattt_12@hotmail.com

Thais Sanches Leite Patara

ORCID: https://orcid.org/0000-0001-6352-7510 University of Western Sao Paulo, Brazil E-mail: thaisslp@hotmail.com

Bianca Eduarda de Lima Neves

ORCID: https://orcid.org/0000-0001-5431-6033

University of Western Sao Paulo, Brazil

E-mail: biancalimaneves1@gmail.com

Marcela Lucio Caldeira

ORCID: https://orcid.org/0000-0001-8749-1903

University of Western Sao Paulo, Brazil

E-mail: ma.lucio.11@ hotmail.com

Luciana Prado Maia

ORCID: https://orcid.org/0000-0001-5697-2587

University of Western Sao Paulo, Brazil

E-mail: lucianapmaia@gmail.com

Christine Men Martins

ORCID: https://orcid.org/0000-0002-5429-509X

University of Western Sao Paulo, Brazil

E-mail: christinemen@hotmail.com

\begin{abstract}
Use of mesenchymal stem cells and low-level laser therapy (LLLT) have been widely studied to promote bone healing. evaluate effect of photobiomodulation on total number of cells (TNC) and cell viability (CV) of fresh bone marrow aspirate (BMA). Femur BMA from 10 adult rats was collected and a cell concentration of $1 \times 10^{7}$ cell $/ \mathrm{mL}$ was obtained. Cell suspension was deposited on 96 well cell culture plates and distributed in groups: 1) RPMI, positive control; 2) Distilled Water, negative control; 3) Red Laser (RL); 4) Infrared Laser (IRL). Groups RL and IRL received LLLT application right after incubation. Cells were incubated for $24 \mathrm{~h}$. TNC and CV were assessed through trypan blue assay after 1, 3, 6, 10 and $24 \mathrm{~h}$ of incubation. Data distribution was verified by Shapiro-Wilk test. Kruskal-Wallis test was used for intergroup and intragroup comparisons ( $\mathrm{p}<0.05)$. TNC: after 1 and $3 \mathrm{~h}$, groups RL and IRL presented significantly higher TNC than Group Water; after 6 and $10 \mathrm{~h}$, groups RPMI, RL and IRL presented significantly higher TNC than Group Water. CV: after $1 \mathrm{~h}$, groups RL and IRL showed significantly higher percentage of VC than Group Water; after 3, 6 and $10 \mathrm{~h}$, all groups presented significantly higher percentage of VC than Group Water. It can be concluded that LLLT enhanced number and viability of fresh bone marrow aspirate cells.
\end{abstract}

Keywords: Cell survival; Bone marrow; Stem cells; Low-level laser therapy; Rats.

\section{Resumo}

$\mathrm{O}$ uso de células-tronco mesenquimais e da terapia a laser de baixa intensidade (LLLT) tem sido amplamente estudado para promover a regeneração óssea. Objetivo: avaliar o efeito da fotobiomodulação no número total de células (NTC) e na viabilidade celular (VC) do aspirado de medula óssea fresco (AMO). Métodos: AMO do fêmur de 10 ratos adultos foi coletado e uma concentração de células de 1 x107 células / $\mathrm{mL}$ foi obtida. A suspensão de células foi depositada em placas de cultura de células de 96 poços e distribuída em grupos: 1) RPMI, controle positivo; 2) Água destilada, controle negativo; 3) Laser Vermelho (LV); 4) Laser infravermelho (LIV). Os grupos LV e LIV 
receberam aplicação de LLLT logo após a incubação. As células foram incubadas por até 24 h. NTC e VC foram avaliados através do ensaio de azul de tripan após 1, 3, 6, 10 e 24 h. A distribuição dos dados foi verificada pelo teste de Shapiro-Wilk. O teste de Kruskal-Wallis foi usado para comparações intergrupos e intragrupos $(p<0,05)$. Resultados: NTC: após 1 e 3 h, os grupos LV e LIV apresentaram NTC significativamente maior do que o Grupo Água; após 6 e 10 h, os grupos RPMI, LV e LIV apresentaram NTC significativamente maior do que o Grupo Água. VC: após $1 \mathrm{~h}$, os grupos LV e LIV apresentaram porcentagem significativamente maior de VC do que o Grupo Água; após 3, 6 e 10 h, todos os grupos apresentaram porcentagem significativamente maior de VC do que o Grupo Água. Conclusões: Pode-se concluir que a LLLT aumentou o número e viabilidade de células do aspirado de medula óssea fresco.

Palavras-chave: Sobrevivente de célula; Medula óssea; Células-tronco; Terapia a laser de baixa intensidade; Ratos.

\section{Resumen}

El uso de células madre mesénquimas y la terapia con láser de bajo nivel (LLLT) se han estudiado ampliamente para promover la curación ósea. Evaluar el efecto de la fotobiomodulación sobre el número total de células (NTC) y la viabilidad celular (VC) del aspirado de médula ósea fresca (AMO). Se recogió BMA de fémur de 10 ratas adultas y se obtuvo una concentración de células de 1 x 107 células/ml. La suspensión celular se depositó en placas de cultivo celular de 96 pocillos y se distribuyó en grupos: 1) RPMI, control positivo; 2) Agua destilada, control negativo; 3 ) láser rojo (LR); 4) Láser infrarrojo (LIR). Los grupos LR e LIR recibieron la solicitud LLLT inmediatamente después de la incubación. Las células se incubaron durante $24 \mathrm{~h}$. El NTC y el VC se evaluaron mediante el ensayo de azul tripán después de 1, 3, 6, 10 y 24 h de incubación. La distribución de los datos se verificó mediante la prueba de Shapiro-Wilk. Se utilizó la prueba de Kruskal-Wallis para las comparaciones entre grupos e intra-grupos (p<0,05). NTC: después de 1 y 3 h, los grupos LR e LIR presentaron NTC significativamente mayor que el Grupo Agua; después de 6 y 10 h, los grupos RPMI, LR e LIR presentaron un NTC significativamente mayor que el Grupo Agua. VC: después de $1 \mathrm{~h}$, los grupos LR e LIR mostraron un porcentaje significativamente mayor de VC que el Grupo Agua; después de 3, 6 y $10 \mathrm{~h}$, todos los grupos presentaron un porcentaje significativamente mayor de VC que el Grupo Agua. Se puede concluir que la LLLT mejoró el número y la viabilidad de las células de la médula ósea fresca.

Palabras clave: Supervivencia celular; Médula ósea; Células madre; Terapia con láser de bajo nivel; Ratas.

\section{Introduction}

Development of biological substitutes for tissue restoration from cell transplantation have been studied by tissue engineering, the major components of regenerative medicine (Zambon et al., 2020). In recent years, the interest of the use of tissue derived cells was aroused because of its therapeutic potential for tissue engineering applications (Ntege et al., 2020).

Studies have evaluated mesenchymal stem cell therapy (MSC) derived from bone marrow with purpose of restore and maintain tissue repair (Burastero et al., 2010; Schneider et al., 2010). Cultivation of MSC is a promising approach, but in vitro processing causes several changes in the phenotype of these cells, which may influence regenerative therapies results (Bara et al., 2014). These phenotypic modifications concerning in vitro cultivation of CTM have led researchers to find alternatives such as the use of unprocessed bone marrow or isolated mononuclear cells (Bara et al., 2014). At a cellular level, these therapeutic approaches could preserve the feature and properties of MSC and their self-renewal capability, which could not only strengthen its therapeutic potential but exclude some disadvantages of cultivation such as development time and costs needed (Bara et al.,2014). Thus, in order to simplify the use of these cells and also to improve their therapeutic potential, fresh bone marrow aspirate (BMA) has been proposed as a viable source of MSC (Santinoni et al., 2020; Nagata et al., 2013). BMA contains a significant percentage of hematopoietic, endothelial and MSC cells (Smiler et al., 2008). Transplantation of autogenous MSC to the site of tissue injury is a promising tool for cell-based strategies necessary for bone regeneration, tissue repair and healing (Smiler et al., 2008).

It has been demonstrated that the exposure of MSC to low level laser therapy [LLLT] can accelerate the proliferation of these cells (Eduardo et al., 2008; Hou et al.,2008) and increase releasing of growth factors, in addition to accelerating cell proliferation of differentiated cells, such as osteoblasts and fibroblastos (Hou et al.,2008). Then, association of LLLT with BMA would also have the potential to promote highly advantageous synergistic results. This hypothesis was confirmed in previous studies (Santinoni et al., 2020; Nagata et al., 2013) where photobiomodulation of fresh BMA was evaluated in critical 
bone defects. Santinoni et al.6 did show LLLT combined with BMA enhanced bone healing improving expression of biomarkers related to angiogenesis, cell proliferation, osteoblast differentiation, and bone maturation (Nagata et al.2013). observed this combination significantly increased bone formation and suggested that LLLT may have stimulated MSC present in BMA and their differentiation into osteoblastic lineage cells, resulting in faster and better bone regeneration This hypothesis is based on osteocalcin analysis is related to the later phase of the bone formation process (Thorwarth et al., 2005).In addition, it has also been suggested that LLLT could have influenced other BMA cells, such as endothelial progenitor cells and hematopoietic stem cells, enhancing their ability to induce vasculogenesis, recruit other cells to the wound site, and secrete growth factors and cytokines which would have a paracrine effect on the adjacent cells (Santinoni et al.,2020; Nagata et al.,2013; Kim et al., 2009; Suh et al., 2005), thus improving bone regeneration (Santinoni et al.,2020; Nagata et al.,2013; Matsumoto et al., 2006).

The inferences about the results of combination BMA/LLLT were made based on previous studies that evaluated the effects of LLLT on cultivated bone marrow MSC to promote tissue regeneration (Kim et al., 2009; Matsumoto et al., 2006). However, its effects on fresh bone marrow cells have not been evaluated.

The purpose of the present in vitro study was to evaluate the effect of LLLT on total number and viability of bone marrow murine cells, through trypan blue assay. Null hypothesis is that laser treatment does not influence the behavior of bone marrow cells.

\section{Methodology}

This animal study was performed after receiving approval of the Ethics Committee on Animal Use (ECAU) in University of Western São Paulo (ECAU approval No. 4589).

Authors followed the ARRIVE (Animal Research: Reporting of in vivo Experiments) guidelines. Ten male rats (Rattus norvegicus, albinus, Wistar) weighing 250 to $300 \mathrm{~g}$ were used. The animals were kept in an environment with 12 hours light cycle per day and controlled temperature between 22 and $24^{\circ} \mathrm{C}$. Throughout the experiment, the animals consumed selected solid feed and water ad libitum.

Immediately after the induction of euthanasia with intraperitoneal injection of Thiopental (100 mg/kg, Thiopentax, Cristália, Brazil), right femur of each animal was collected and sectioned at its extremities. The bone marrow cells were flushed into a falcon tube using a syringe and needle with $3 \mathrm{ml}$ of RPMI cell culture medium.

Cell concentration was adjusted in 1 x 107 cells $/ \mathrm{mL}$ thru a Neubauer chamber. At that time, the initial cell viability was recorded.

Seventy microliters $(70 \mu \mathrm{l})$ of the cell solution were deposited in 96 well cell culture plates (TTP-Techno Plastic Products, Trasadingen, Swiss). The samples were incubated in triplicate and distributed in the following experimental groups: 1) RPMI, as positive control; 2) Distilled Water, as negative control; 3) Red Laser (RL); 4) Infrared Laser (IRL). RPMI and water groups, the cells were incubated in wells containing $70 \mu \mathrm{l}$ of RPMI or distilled water, respectively. In the RL and IRL groups, the cells were incubated in wells containing $70 \mu \mathrm{l}$ of RPMI and received application of LLLT immediately after incubation, following the protocols described below.

To avoid interference between the evaluated treatments, the cells of each animal were incubated individually in 96 well cell culture plates.

Criteria based on previous studies were followed (Santinoni et al., 2020; Nagata et al., 2013). Indium-galliumaluminum-phosphorus laser (InGaAlP) (PhotonLase ${ }^{\circ}$ III, DMC Equipamentos Ltda, São Carlos, SP, Brazil) was used. In the Red Laser Group, a wavelength of $660 \mathrm{~nm}$ (InGaAlP) was used. In the Infrared Laser Group, a wavelength of $808 \mathrm{~nm}$ (AsGaAl) was used. LLLT was applied following the protocol: contact mode, at 8 points equidistant in the well entrance 
internal aspect of the cell culture plates (diameter $6.4 \mathrm{~mm}$ and growth area of $0.31 \mathrm{~cm} 2$ ), in such a way that its entire extension received the laser irradiation. The laser parameters used per point were power of $0.030 \mathrm{~W}$, time $9 \mathrm{~s}$, energy $2.7 \mathrm{~J}$, power density $1.06 \mathrm{~W} / \mathrm{cm} 2$, and energy density $9,54 \mathrm{~J} / \mathrm{cm} 2$.

Cell culture plates were incubated at room with controlled temperature at $21^{\circ} \mathrm{C}$ during $24 \mathrm{~h}$. The samples were analyzed after 1, 3, 6, 10 and $24 \mathrm{~h}$. Total number of cells and cell viability was tested 5 times for each storage medium. The viability was determined through microscopic analysis of the cells excluded by trypan blue staining, a vital dye derivative of toluidine according to Martins et al. (2016). Part of each sample was placed in a Neubauer chamber with equal volume of dye. Stained cells or those presenting ballooning degeneration were assumed as dead. Two examiners conducted the analyses, and the results were shown in percentage. Total number of cells was obtained through the sum of viable cells and dead cells.

The data collected were tabulated, considering the animal as the statistical unit. For all statistical analyzes, a significance level of $5 \%$ was adopted. The data were grouped and presented as means and standard deviations (continuous variables). Cell viability was calculated as a percentage of the total number of cells initial. The distribution of the data was verified by the Shapiro-Wilk test. The non-parametric Kruskal-Wallis test was used for intergroup and intragroup comparisons. SPSS (IBM SPSS Statistics) v.21 software was used to perform these analyzes.

\section{Results}

After 1 and 3 hours of cell incubation, groups RL ( $\mathrm{p}=0.023 ; \mathrm{p}=0.002)$ and IRL $(\mathrm{p}=0.022 ; \mathrm{p}=0.000)$ presented significantly higher total number of cells than Group Water. After 6 and 10 hours of cell incubation, groups RPMI ( $\mathrm{p}=0.025$; $\mathrm{p}=0.022), \mathrm{RL}(\mathrm{p}=0.013 ; \mathrm{p}=0.021)$ and IRL $(\mathrm{p}=0.009 ; \mathrm{p}=0.018)$ presented significantly higher total number of cells than Group Water. After 24 hours of cell incubation, no statistically significant differences were observed among experimental groups.

Intragroup comparisons: Group RPMI after 10 hours ( $\mathrm{p}=0.001 ; \mathrm{p}=0.001)$ and 24 hours $(\mathrm{p}=0.018 ; \mathrm{p}=0.024)$ of cell incubation, presented significantly higher total number of cells than 1 and 3 hours. Group Water after 10 hours ( $\mathrm{p}=0.001$; $\mathrm{p}=0.000 ; \mathrm{p}=0.004)$ and 24 hours $(\mathrm{p}=0.012 ; \mathrm{p}=0.003 ; 0.037)$ of cell incubation, presented significantly higher total number of cells than 1, 3 and 6 hours. Group RL after 10 hours ( $\mathrm{p}=0.013$; $\mathrm{p}=0.027)$ of cell incubation, presented significantly higher total number of cells than 1 and 3 hours. Group IRL showed no statistically significant differences over time.

After 1 hour of cell incubation, groups RL ( $\mathrm{p}=0.000)$ and IRL ( $\mathrm{p}=0.001)$ had a significantly higher percentage of viable cells than Group Water. After 3, 6 and 10 hours, RPMI ( $p=0.007 ; p=0.000 ; p=0.012$ ), RL ( $p=0.000 ; p=0.000 ; p=0.004$ ) and IRL ( $\mathrm{p}=0.000 ; \mathrm{p}=0.000 ; \mathrm{p}=0.002$ ) groups had a significantly higher percentage of viable cells than Group Water. After 24 hours, no statistically significant differences were observed among experimental groups.

Intragroup comparisons showed no statistically significant differences among the experimental groups in the analyzed periods.

Qualitatively, it was observed an increase on total number and cell viability in the groups treated with both lasers over time compared with groups RPMI and Water. After 6 hours, it could be observed an increased total number of cells and percentage of viable cells which was maintained over time.

Figure 1 represents the characterization of cells stained (dead) or not (viable) with trypan blue. Figure 2 shows total number of cells of each treatment performed over time with intergroup comparisons. Figure 3 shows the mean percentage of cell viability related to the total number of cells of each treatment performed over time. 
Figure 1. Characterization of cells stained or not with trypan blue. Blue arrows represent dead cells because had dye incorporation in the cytoplasm. Green arrows represent viable cells because their membrane was kept intact. Analysis in Neubauer chamber. 40x, trypan blue assay.

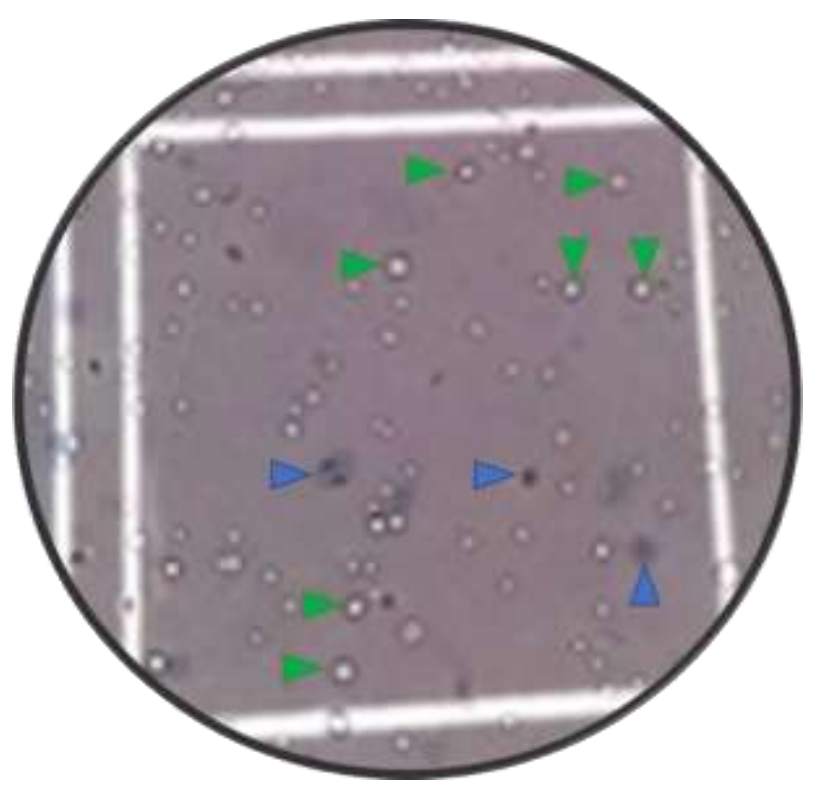

Source: Authors.

Figure 2. Average of total number of cells in groups RL, IRL and controls throughout the experimental period, with intergroup comparisons. Trypan blue assay, readings performed in triplicate by two previously trained observers with four repeats.

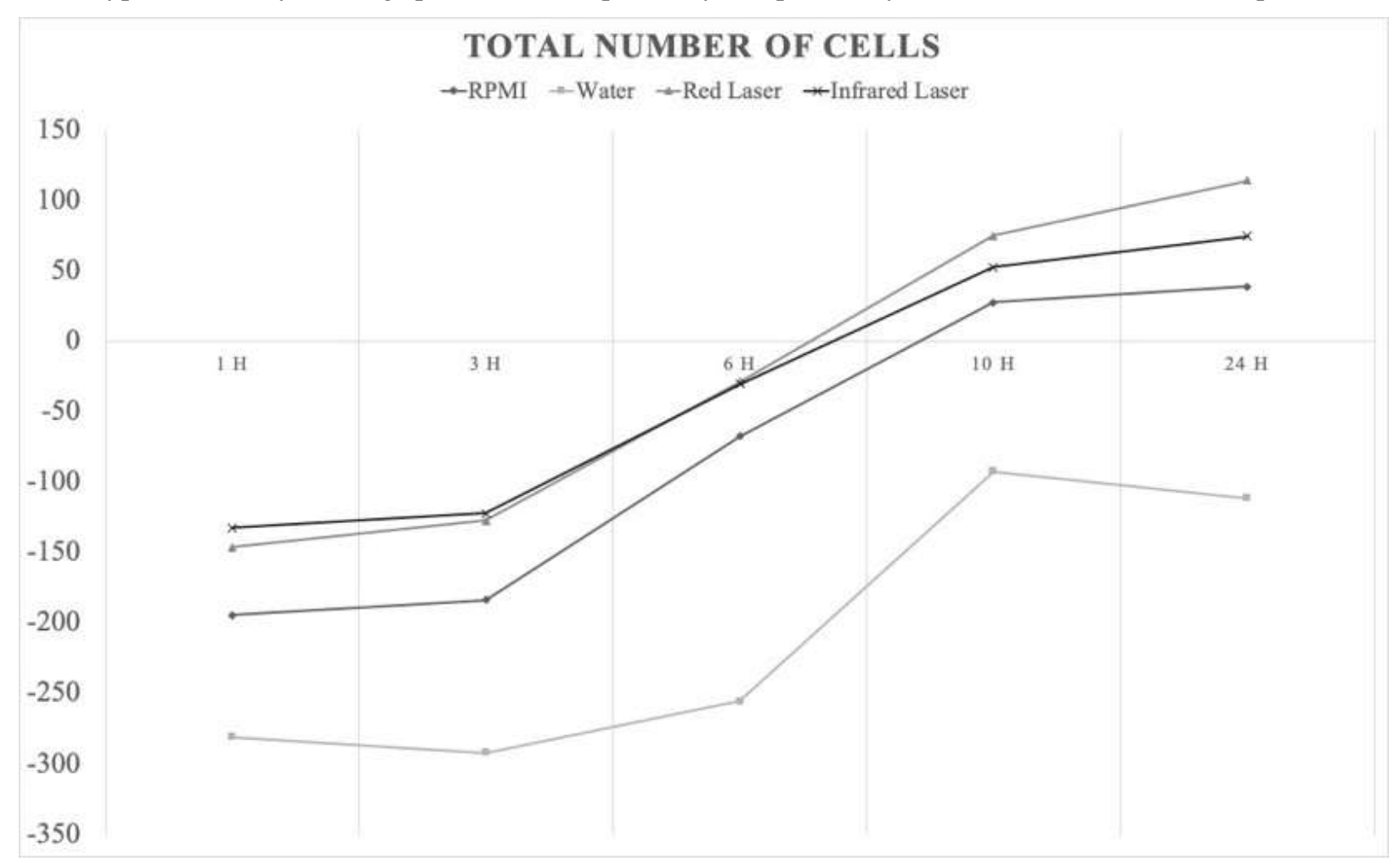

Source: Authors. 
Figure 3. Average of cell viability in groups RL, IRL and controls throughout the experimental period. Trypan blue assay, readings performed in triplicate by two previously trained observers with four repeats.

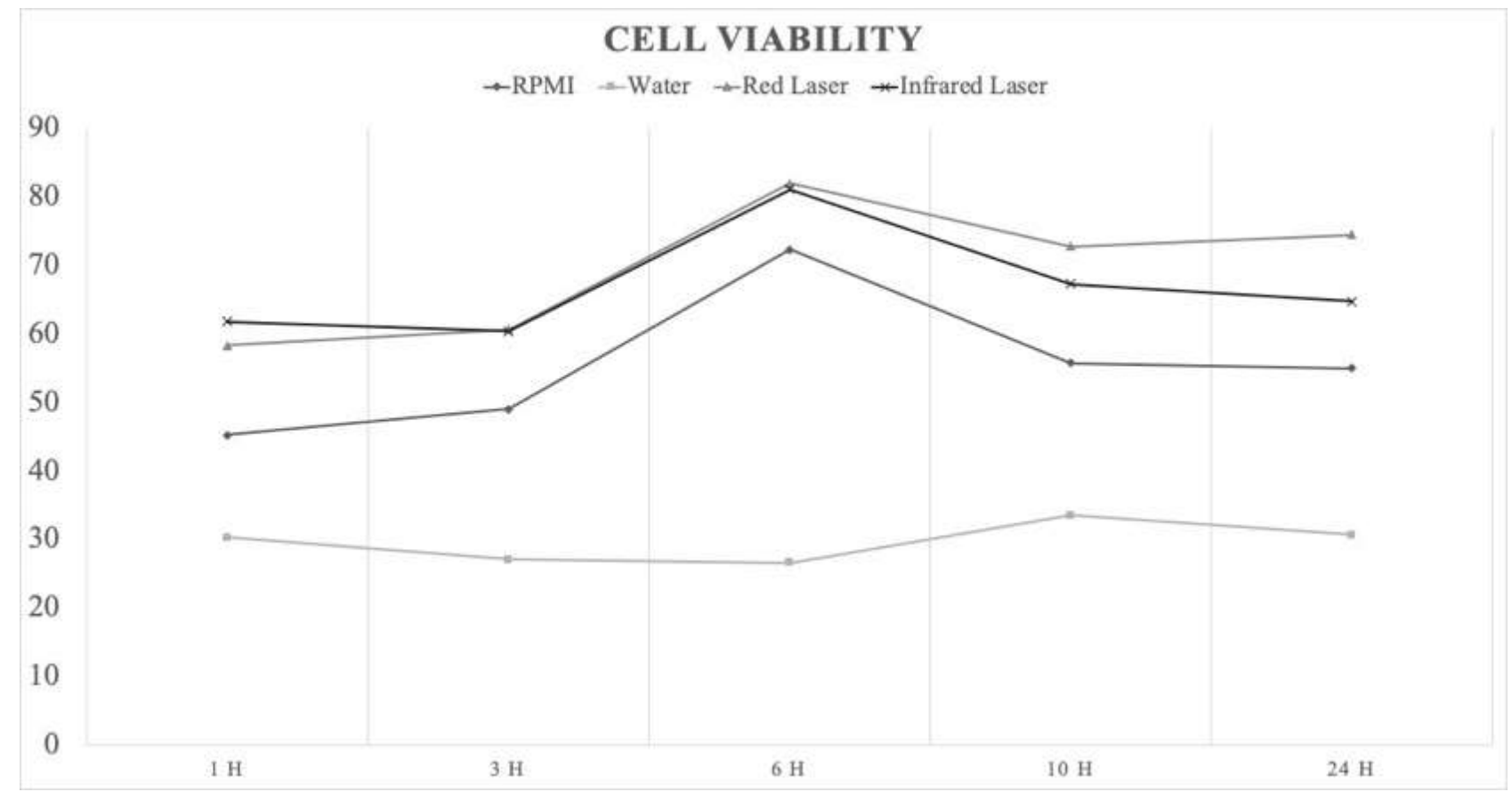

Source: Authors.

\section{Discussion}

MSC are multipotent cells that have replication capacity in undifferentiated cells and can differentiate into mesenchymal tissue strains, including bone, cartilage, adipose tissue, tendons, muscles, and medullary stroma (Pittenger et al., 1999; Maria et al., 2007). Nowadays, MSC have been applied to promote repair or regeneration of injured or modified tissues (Wang et al., 2016). The present study was delineated from the promising results observed in previous studies (Santinoni et al., 2020; Nagata et al., 2013) where the combination of BMA (as the source of MSC) and LLLT demonstrated benefits over the repair of critical bone defects surgically created in rat calvaria. In order to better evaluate the effect of LLLT on bone marrow cells, total number of cells and cell viability rate were assessed through the trypan blue assay. It was observed high ability of the RL and IRL to maintain viability and possibly stimulate cell growth and/or proliferation. So, null hypothesis that laser treatment does not influence the behavior of bone marrow cells was denied.

Bone marrow was the source of choice for obtaining MSC based on previous studies that demonstrated a better osteogenic potential of bone marrow MSC when compared to other anatomical origins (Schneider et al., 2010; Zhang et al.,2009). However, it is important to consider that MSC can be obtained from many other tissues such as dental pulp (Shi et al., 2003), adipose tissue (Woodruff et al., 2004) and umbilical cord (Vieira et al.,2008).

Some authors believe that the bone marrow has not enough number of MSC to be used without in vitro expansion (Burastero et al., 2010; Kraus, Kirker-Head., 2006). In fact, there is little scientific evidence to correlate the number of cells with clinical efficacy in terms of tissue repair or regeneration (Tolar et al., 2010). However, it is important to consider the MSC environment that despite distinct anatomical origins, divide their niches with many other cell types. At bone marrow, it includes osteoblasts and hematopoietic stem cells. These different cell types present a connection and seem to regulate cellular behavior (Bara et al.,2014). In addition, it is important to consider that LLLT may have a positive influence not only on MSC but also on those other cells. Bone marrow also have endothelial progenitors and hematopoietic stem cells (Matsumoto et al., 2006). Then, it could be suggested that LLLT could also enhance their ability to induce vasculogenesis, recruit other cells to 
the wound site and secrete growth factors and cytokines that have effect on the adjacent cells (Santinoni et al., 2020; Nagata et al., 2013; Kim et al., 2009; Suh et al., 2005), thus improving bone regeneration (Matsumoto et al., 2006). The results of the present study corroborate to those previously observed (Santinoni et al., 2020; Nagata et al., 2013) demonstrating that photobiomodulation of bone marrow cells may be a promising tool to obtain results as good as those observed when MSC cultivation and expansion are performed.

In the present study, it was observed that the groups treated with red or infrared lasers presented a higher total number of cells and cell viability rate compared to control (Group Water) in all analyzed periods. These results demonstrate that LLLT has improved the survival of bone marrow cells over time and may help explain the results observed in the studies by Santinoni et al. (2020) and Nagata et al (2013). It can be inferred that the LLLT applied on the bone marrow allowed the cells to be viable longer to promote the tissue repair at the site of the injury. Previous studies have demonstrated that the possible mechanism of action of LLLT on cells is caused by altered protein expression through stimulation of the production of adenosine triphosphate (ATP), DNA and RNA synthesis, activation of signaling cascades and activity modification of cell organelles (Houreld et al., 2012). In this context, it is important to consider that a greater number of living cells were competing for available nutrients in the wells. Still, the cells remained viable over time. It can be inferred that these results corroborate those of Eduardo et al (2008). where LLLT was able to increase cell proliferation even under nutritional deficiency conditions.

Regarding to the LLLT protocols used in the present study, it was observed that both red laser $(660 \mathrm{~nm})$ and infrared laser $(808 \mathrm{~nm})$ promoted increased cell viability. However, there was a difference on total number of cells and cell viability over time when compared to the different wavelengths used. After 1 and 3 hours of cell incubation, the infrared laser presented better results. After 6 hours, the results of total number of cells and cell viability for both types of lasers matched. Contrastingly, after 10 and 24 hours of cell incubation, the red laser presented the highest total number of cells and cell viability rates. These results suggest that both type of lasers enhanced cell proliferation and viability. But if it is desirable that the effects of the LLLT on bone marrow cells remain for a longer time during the healing process, it can be inferred that the red laser shows the best results. The influence of different LLLT parameters on the results obtained is widely evaluated and discussed in the literature. Several studies have demonstrated that different cell lines respond differently to specific combinations of wavelengths and doses of LLLT (Santinoni et al., 2017; Fekrazad et al., 2019). Here, the red laser showed the best results over time, allowing the cells to be viable longer when compared to the infrared laser.

RPMI was selected as a culture medium to obtain a positive control that reduces cell damage and improves cell proliferation (Martins et al., 2016). Distilled water was used as a culture medium to obtain a negative control as it exhibits microbial contamination, hypotonicity, $\mathrm{pH}$ and osmolarity beyond the physiological limits that cause cell lysis (Martins et al., 2016). In fact, the results demonstrated a negative effect of water on total number of cells and cell viability in all analyzed periods when compared to RPMI and the other treatments.

Limitations of the study were related to the absence of a group that incubated cells in water associated with LLLT application to verify whether LLLT could have influenced total number and viability of bone marrow cells even under nutrient shortage conditions.

\section{Conclusion}

Within the limits of the present study, it can be concluded that LLLT enhanced number and viability of fresh bone marrow cells. Further studies are needed to evaluate the effect of LLLT on bone marrow cells, in addition to future comparisons between the regenerative potential of the BMA/LLLT combination and cultured MSC on bone healing. 


\section{Acknowledgments}

The authors thank University of Western São Paulo (\#4589) for partially support this study and Douglas Roberto Monteiro for material donation.

\section{References}

Bara, J. J., Richards, R. G., Alini, M. \& Stoddart, M. J. (2014). Concise review: Bone marrow-derived mesenchymal stem cells change phenotype following in vitro culture: implications for basic research and the clinic. Stem Cells, 32, 1713-1723.

Burastero, G., Scarfî, S., Ferraris, C., Fresia, C., Sessarego, N., Fruscione, F., Monetti, F., Scarfò, F., Schupbach, P., Podestà, M., Grappiolo, G. \& Zocchi, E. (2010). The association of human mesenchymal stem cells with BMP-7 improves bone regeneration of critical-size segmental bone defects in athymic rats Bone, 47, 117-126.

Eduardo, F. P., Bueno, D. F., De Freitas, P. M., Marques, M. M., Passos-Bueno, M. R., Eduardo, C. De P. \& Zatz, M. (2008). Stem cell proliferation under low intensity laser irradiation: a preliminary study. Lasers Surg Med, 40, 433-438.

Fekrazad, R., Asefi, S., Eslaminejad, M. B., Taghiar, L., Bordbar, S. \& Hamblin, M. R. (2019). Photobiomodulation with single and combination laser wavelengths on bone marrow mesenchymal stem cells: proliferation and differentiation to bone or cartilage. Lasers Med Sci, 34, 115-126.

Hou, J. F., Zhang, H., Yuan, X., Li, J., Wei, Y. J. \& Hu, S. S. (2008). In vitro effects of low-level laser irradiation for bone marrow mesenchymal stem cells: proliferation, growth factors secretion and myogenic differentiation. Lasers Surg Med, 40, 726-733.

Houreld, N. N., Masha, R. \& Abrahamse, H. (2012). Low intensity laser irradiation at $660 \mathrm{~nm}$ stimulates cytochrome c oxidase in stressed fibroblast cells. Lasers Surg Med, 44, 429-434.

Kim, K. L., Han, D. K., Park, K., Song, S. H., Kim, J. Y., Kim, J. M., Ki, H. Y., Yie, S. W., Roh, C. R., Jeon, E. S., Kim, D. K. \& Suh W. (2009). Enhanced dermal wound neovascularization by targeted delivery of endothelial progenitor cells using an RGD-g-PLLA scaffold. Biomaterials, 30, $3742-3748$.

Kraus, K. H. \& Kirker-Head, C. (2006). Mesenchymal stem cells and bone regeneration. Vet Surg, 35, 232-242.

Maria, O. M., Khosravi, R., Mezey, E. \& Tran, S. D. (2007). Cells from bone marrow that evolve into oral tissues and their clinical applications. Oral Diseases, 3, 11-16.

Martins, C. M., Hamanaka, E. F., Hoshida, T. Y., Sell, A. M., Hidalgo, M. M., Silveira, C. S. \& Poi, W. R. (2016). Dragon's Blood Sap (Croton Lechleri) As Storage Medium For Avulsed Teeth: In Vitro Study Of Cell Viability. Braz Dent J, 27, 751-756.

Matsumoto, T., Kawamoto, A., Kuroda, R., Ishikawa, M., Mifune, Y., Iwasaki, H., Miwa, M., Horii, M., Hayashi, S., Oyamada, A., Nishimura, H., Murasawa, S., Doita, M., Kurosaka, M. \& Asahara, T. (2006). Therapeutic potential of vasculogenesis and osteogenesis promoted by peripheral blood CD34-positive cells for functional bone healing. Am J Pathol, 169, 1440-1457.

Nagata, M. J., Santinoni, C. S., Pola, N. M., De Campos, N., Messora, M. R., Bomfim, S. R., Ervolino, E., Fucini, S. E., Faleiros, P. L., Garcia, V. G. \& Bosco, A. F. (2013). Bone marrow aspirate combined with low-level laser therapy: A new therapeutic approach to enhance bone healing. $J$ Photochem Photobiol B, 121, 6-14.

Ntege, E. H., Sunami, H. \& Shimizu, Y. (2020). Advances in regenerative therapy: A review of the literature and future directions. Regenerative Therapy, 14, 136-153.

Paulo Zambon, J., Atala, A., Yoo, J. J. (2020). Methods to generate tissue-derived constructs for regenerative medicine applications. Methods, 171, 3-10.

Pittenger, M. F., Mackay, A. M., Beck, S. C., Jaiswal, R. K., Douglas, R., Mosca, J. D., Moorman, M. A., Simonetti, D. W., Craig, S. \& Marshak, D. R. (1999). Multilineage potential of adult human mesenchymal stem cells. Science, 284, 143-147.

Santinoni, C. S., Neves, A. P. C., Almeida, B. F. M., Kajimoto, N. C., Pola, N. M., Caliente, E. A., Belem, E. L. G., Lelis, J. B., Fucini, S. E., Messora, M. R., Garcia, V. G., Bomfim, S. R. M., Ervolino, E. \& Nagata, M. J. H. (2021). Bone marrow coagulated and low-level laser therapy accelerate bone healing by enhancing angiogenesis, cell proliferation, osteoblast differentiation, and mineralization. J Biomed Mater Res A, 109(6), 849-858.

Santinoni, C. S., Oliveira, H. F. F., Batista, V. E. S., Lemos, C. A. A., \& Verri, F. R. (2017). Influence of low-level laser therapy on the healing of human bone maxillofacial defects: A systematic review. J Photochem Photobiol B, 169, 83-89.

Schneider, R. K., Puellen, A., Kramann, R., Raupach, K., Bornemann, J., Knuechel, R., Pérez-Bouza, A. \& Neuss, S. (2010). The osteogenic differentiation of adult bone marrow and perinatal umbilical mesenchymal stem cells and matrix remodelling in three-dimensional collagen scaffolds. Biomaterials, 31, 467480 .

Shi, S. \& Gronthos, S. (2003). Perivascular niche of postnatal mesenchymal stem cells in human bone marrow and dental pulp. J Bone Miner Res, 18, 696704.

Smiler, D., Soltan, M. \& Albitar, M. (2008). Toward the identification of mesenchymal stem cells in bone marrow and peripheral blood for bone regeneration. Implant Dentistry, 17, 236-247.

Suh, W., Kim, K. L., Kim, J. M., Shin, I. S., Lee, Y. S., Lee, J. Y., Jang, H. S., Lee, J. S., Byun, J., Choi, J. H., Jeon, E. S. \& Kim, D. K. (2005). Transplantation of endothelial progenitor cells accelerates dermal wound healing with increased recruitment of monocytes/macrophages and neovascularization. Stem Cells, 23, 1571-1578. 
Research, Society and Development, v. 10, n. 11, e140101119545, 2021

(CC BY 4.0) | ISSN 2525-3409 | DOI: http://dx.doi.org/10.33448/rsd-v10i11.19545

Tolar, J., Le Blanc, K., Keating, A., \& Blazar, B. R. (2010). Concise review: hitting the right spot with mesenchymal stromal cells. Stem Cells, 28, $1446-1455$.

Thorwarth, M., Rupprecht, S., Falk, S., Felszeghy, E., Wiltfang, J. \& Schlegel, K. A. (2005). Expression of bone matrix proteins during de novo bone formation using a bovine collagen and platelet-rich plasma (PRP)—an immunohistochemical analysis. Biomaterials, 26, 2575-2584.

Vieira, N. M., Brandalise, V., Zucconi, E., Jazedje, T., Secco, M., Nunes, V. A., Strauss, B. E., Vainzof, M. \& Zatz, M. (2008). Human multipotent adipose derived stem cells restore dystrophin expression of Duchenne skeletal muscle cells in vitro. Biol Cell, 100, 231-241.

Wang, Q., Yang, Q., Wang, Z., Tong, H., Ma, L., Zhang, Y., Shan, F., Meng, Y., Yuan, Z. (2016). Comparative analysis of human mesenchymal stem cells from fetal-bone marrow, adipose tissue, and Warton's jelly as sources of cell immunomodulatory therapy. Hum Vaccin Immunother, 12, 85-96.

Woodruff, L. D., Bounkeo, J. M., Brannon, W. M., Dawes, K. S., Barham, C. D., Waddell, D. L. \& Enwemeka, C. S. (2004). The efficacy of laser therapy in wound repair: A meta-analysis of the literature. Photomed Laser Surg, 22, 241-247.

Zhang, Z. Y., Teoh, S. H., Chong, M. S., Schantz, J. T., Fisk, N. M., Choolani, M. A., Chan, J. (2009). Superior osteogenic capacity for bone tissue engineering of fetal compared with perinatal and adult mesenchymal stem cells. Stem Cells, 27, 126-137. 